\title{
The Effect Of Information Asymmetry, Company Size And Managerial Ownership On Income Management \\ (Empirical Study on Manufacturing Companies Listed on the Indonesia Stock Exchange)
}

Farid Addy Sumantri

farid.sumantri@ubd.ac.id ${ }^{1}$ )

Agus Kusnawan')

Agus.kusnawan@ubd.ac.id

Rr. Dian Anggraeni $\left.{ }^{3}\right)$

dian.anggraeni@buddhidharma.ac.id

1) 2) 3) Buddhi Dharma University Tangerang, Banten, Indonesia.

\begin{abstract}
Earnings Management is the action of a manager by presenting reports that increase or decrease profit for the current period of the business unit for which is responsible, without causing an increase or decrease in the unit's long-term economic profitability. The purpose of this study was to examine the effect of information asymmetry, Company Size and Management ownership of Earnings Management in various industry sector companies listed on the Indonesia Stock Exchange 2017-2019.

The sample used in this study consisted of 93 samples of various industrial, basic and chemical sector companies listed on the Indonesia Stock Exchange during the 20172019 periods. The sample was selected using purposive sampling method. Earnings management is proxied by Discretionary Accrual using the Modified Jones Model. The data analysis method used in this research is multiple linear regression analysis.

The results showed that information asymmetry has an effect on earnings management, firm size has no effect on earnings management, and management ownership has no effect on earnings management. The results of this study also prove that simultaneously information asymmetry, firm size and managerial ownership have an effect on earnings management
\end{abstract}

Keywords: Information Asymmetry, Company Size, Managerial Ownership and Earnings Management. 


\section{BACKGROUND}

In companies, information asymmetry often occurs between managers as agents and shareholders as users of financial statements, which causes shareholders to not be able to observe all the performance and prospects of the company perfectly. Information asymmetry is a situation that is formed because the principal (shareholder) does not have sufficient information about the agent's (manager's) financial performance so that the principal can never determine the contribution of the agent's efforts to actual company results (Wiryadi and Sebrina, 2013).

According to Anthony and Govindarajan (2005) the condition of information asymmetry appears in agency theory, where the principal (owner / boss) gives the agent authority to regulate the company he owns. The principal does not have sufficient information about the agent's performance, the principal never knows for sure how the agent's effort contributes to the company's accrual results, and this situation is called information asymmetry.

The existence of information asymmetry is considered to be the cause of earnings management. The more internal information the manager has than shareholders, the more managers will have the opportunity to do earnings management (Arief and Bambang, 2007) in (Wiryadi and Sebrina, 2013). This is also in line with research by Richardson (1998) in Desmiyawati, et al. (2009) which states that there is a positive relationship between information asymmetry and earnings management. When information asymmetry is high, stakeholders do not have sufficient resources regarding incentives or access to relevant information to monitor managers' actions. This will provide opportunities for managers to manage earnings (earnings management).

Firm size is also an important variable in this study. Company size is a scale that can be classified according to the size of the company. Veronica and Utama (2005) in Desmiyawati, et al (2009) prove that the bigger the company size, the smaller the level of profit management. Large companies have a large enough incentive to carry out earnings management, because one of the main reasons is that large companies must be able to meet the expectations of their investors or shareholders, besides that the bigger the company, the more estimates and judgments that need to be applied to each type of company activity growing (Santi, 2008) in Agusti and Pramesti (2009)

Managerial ownership is the percentage of shares owned by management and a factor that can affect the running of the company which ultimately affects the financial statements. This is due to the control they have (Wiryadi and Sebrina, 2013). In general, it can be said that a certain percentage of share ownership by management tends to influence earnings management actions (Kusumawardhani, 2012). Jensen and Meckling (1976) stated that to minimize agency conflict is to increase managerial ownership in the company. Managerial ownership is a control mechanism that can be exercised by shareholders to reduce earnings management.

By giving managers the opportunity to be involved in share ownership with the aim of equalizing the interests of shareholders, the manager's desire to maximize his own profits by performing earnings management will be reduced. This is because managers participate in determining accounting policies and procedures taken by the company, so that the higher the managerial ownership, the less earnings management will be carried out because the manager will share in every decision taken (Wiryadi and Sebrina, 2013). 
The phenomenon that has occurred regarding earnings management, which has increased in recent years, involves many parties and comprehensive impact, causing a decline in the trust of users of financial statements. From the financial report data of PT Bumi Resources Tbk (Halid, 2012), the company's profit has increased every year which indicates that the company is good, but there is an imbalance between the profits earned and the existing share prices. Where should high profits be able to increase share prices and vice versa when company profits fall, the stock price usually goes down. This happened in 2004 to 2005 where the profit earned from 1,079,520 to $1,222,099$ but the stock price actually fell from 800 to 760 .

The existence of this imbalance assumes that there has been a practice of earnings management by management using the income maximization pattern for the benefit of themselves and the company by using existing information asymmetry by looking at the highest and lowest price shares. More information held by managers than other parties is a driving force in carrying out earnings management practices (Halid, 2015).

Research on information asymmetry, firm size and managerial ownership on earnings management has been conducted by previous researchers which showed inconsistent results. Desmiyawati, et al (2009) conducted a study on the effect of information asymmetry on earnings management in manufacturing companies listed on the Indonesia Stock Exchange, The results show that information asymmetry and firm size have a significant positive effect on earnings management. However, Wiryadi and Sebrina (2013) found a significant negative result between information asymmetry on earnings management. Wiryadi and Sebrina (2013) found a significant negative influence between managerial ownership and earnings management. However, Agusti and Pramesti (2013) found that managerial ownership has a significant positive effect on earnings management.

This study is a replication of previous research conducted by Desmiyawati et al. (2009). Desmiyawati, et al conducted a study on the effect of information asymmetry and company size on earnings management practices in manufacturing companies listed on the Indonesia Stock Exchange. The results of his research indicate that the independent variable information asymmetry has a significant positive effect and company size has a significant positive effect. This study investigates the existence of management behavior in earning management and examines the factors that influence it.

The difference between this study and previous research is the independent variable used. Previous researchers only used information asymmetry and firm size as independent variables; therefore, the authors add managerial ownership as an independent variable because to minimize agency conflict is to increase managerial ownership in the company (Jesen and Meckling, 1976) in Kusumawardhani (2012).

The importance of this research is because in practice earnings management is considered to reduce the quality of a company's financial statements. Other than that this action can harm investors because they will get inappropriate information about the company's financial position. Testing into the Indonesian context is very important because it shows that Indonesia is in a country with weak investor protection, so that the tendency for agents to take earnings management actions is quite high. 


\section{REVIEW OF THEORY AND HYPOTHESIS DEVELOPMENT}

Agency theory

Agency theory describes the company as a meeting point between the company owner (principal) and management (agent). Jensen and Meckling (1976) in Rahmawati, et al. (2006) stated that the agency relationship is a contract that occurs between the manager (agent) and the company owner (principal). The authority and responsibilities of both the agent and the principal are regulated in a work contract with mutual consent.

Agency theory assumes that each individual is motivated by self-interest, giving rise to a conflict of interest between the principal and agent. Shareholders as the principal parties enter into contracts to maximize their welfare with increasing profitability. Managers as agents are motivated to maximize the fulfillment of their economic and psychological needs, among others in terms of obtaining investment, loans, and compensation contracts (Widyaningdyah, 2001).

Agency problems arise because of the opportunistic behavior of the agent, namely the behavior of management to maximize their own welfare which is against the interests of the principal. Managers have the urge to choose and apply accounting methods that can show good performance for the purpose of getting bonuses from the principal (Oktafia, 2011).

\section{Profit management}

Earnings management is an intervention in the external financial reporting process with the aim of benefiting oneself. Earnings management is also one factor that can reduce the credibility of financial reports, Earnings management adds to the bias in financial statements and can annoy users of financial statements who believe that these engineered earnings figures are unmanaged profit figures (Setiawan and Na'im, 2000) in Rahmawati, et al (2006).

Earnings management behavior can be explained by agency theory. As an agent, the manager is morally responsible for optimizing the profits of the principals (owners) through earnings reporting. In return for the agent's performance, the principal will provide the agent with an appropriate compensation or bonus. In this case, there are two different interests between principal and agent. Each party will try to increase its profits (Desmiyawati, 2009).

\section{Earnings Management Motivation}

Earning management behavior can be explained in Positive Accounting Theory (PAT) and agency theory. Three hypotheses in the PATH theory that can be used as a basis for understanding the motivation for earnings management actions according to Watt and Zimmerman (1990) in Desmiyawati (2009), namely:

1. Bonus Plan Hypothesis

This hypothesis states that managers in companies with bonus planning tend to use accounting methods that will increase current income.

2. Debt Covenant Hypothesis

This hypothesis states that all other things remain the same and the closer the company is to the debt covenant violation and the greater the probability of the debt covenant violation, the manager uses an accounting method that will increase reported earnings in future periods to the present period. 


\section{Political Cost Hypothesis}

This hypothesis states that if a large company has high political costs, managers will prefer an accounting method that can reduce reported earnings from the present period to the future. This purpose is to avoid government regulations or decisions. For example: raising corporate income tax.

\section{Information Asymmetry}

Information asymmetry is a condition where the agent has more information about the company and its prospects in the future than the principal. This condition provides an opportunity for agents to use the information they know to manipulate financial reporting in an effort to maximize their prosperity. This information asymmetry results in moral hazard in the form of management's efforts to implement earnings management (Rahmawati, et al. 2006).

According to Scott (2000), there are two kinds of information asymmetry, namely:

1. Adverse Selection, that is, managers and other insiders usually know more about the company's circumstances and prospects than outsiders. And there may be facts that are not submitted to the principal.

2. Moral Hazard, that is, managers and other insiders usually know more about the company's circumstances and prospects than outsiders. And there may be facts that are not submitted to the principal.

Schift and Lewin (1970) in Ujiyanto, et al (2007), state that agents are in a position to have more information about their capacity, work environment and the company as a whole compared to principals. Assuming that individuals act to maximize their own interests, the information asymmetry they have will encourage the agent to hide some information that is unknown to the principal. So that in this condition the principal is often as a disadvantage.

\section{Company Size}

Desmiyawati, et al (2009) stated that large companies have a broader base of stakeholders, so various policies of large companies will have a greater impact on public interests than small companies. For investors, the company's policy will have implications for future cash flow prospects. Meanwhile, the regulator (government) will have an impact on the amount of tax to be received, as well as the effectiveness of the role of providing protection for the general public.

Muliati (2011) in Dhaneswari and Widuri (2013) states that company size is a scale where the size of the company can be clarified according to various ways, including: log total assets (Nasution, Maribot and Doddy, 2007), log total sales (Nuryaman, 2008) ), market capitalization (Halim, et al. 2005). Machfoedz (1994) in Mardiyah and Gudomo (2001) explains that basically company size is only divided into 3 categories, namely large firms, medium firms and small firms. Determination of the size of this company is based on the total assets of the company.

\section{Managerial ownership}

Jesen and Meckling (1976) in Listyani (2003), say that the increase in managerial ownership in the company encourages managers to create optimal company 
performance and motivates managers to act prudently, because they share the consequences for their actions.

Jasen and Meckling (1976) in Fidyati and Tyas (2005) determine evidence that managerial ownership is successful as a mechanism to reduce agency problems and moral hazard from managers by aligning the interests of managers with shareholders. The interests of managers and external shareholders can be reconciled if share ownership by managers is enlarged so that managers will not manipulate earnings for their own interests.

\section{Hypothesis Formulation}

Based on the theoretical basis that has been stated previously, the following hypothesis can be formulated:

\section{Information Asymmetry on Earnings Management}

One of the factors in the occurrence of earnings management actions within the company is the asymmetry of information between the company manager (agent) and the owner (principal). Information asymmetry is a condition in which managers have access more information about the company's overall prospects that are not owned by external parties (Wiryadi and Sebrina, 2013).

In the asymmetry it is stated that if both parties (agent and principal) are the people who seek to maximize their utility, hence there are strong reasons to believe that the agent will not always act to maximize the principal's profit. Principals can limit the agent's behavior by setting incentives / bonuses in accordance with the agent's performance and monitoring to minimize the agent's behavior (Wiryadi and Sebrina, 2013).

Research conducted by Desmiyawati et al. (2009) examined the relationship of information asymmetry and earnings management in manufacturing companies. The results of their research showed that there was a significant positive relationship between information asymmetry and earnings management. The existence of information asymmetry is considered as the cause of earnings management. Meanwhile, Wiryadi and Sebrina (2013) examined the effect of information asymmetry on a significant negative effect on earnings management.

Based on the description above, an alternative hypothesis can be formulated which is stated as follows:

\section{$\mathrm{H}_{1}$ : Information asymmetry has a significant effect on earnings management.}

\section{Company Size on Earnings Management}

Company size is a value that shows the size of the company. There are various proxies that are usually used to represent company size, namely the number of employees, total assets, total sales, and market capacity. The bigger the asset, the more capital invested, the more sales, the more money circulation is and the greater the pasa capital, the greater it is known in society (Sudarmadji and Sularto, 2007).

Companies that are large in size usually have a role as shareholders of broad interests. This makes various policies of large companies have a greater impact on public interest than small companies. Therefore, large companies will be noticed by the public so that they will be more careful in carrying out financial reporting, so that the condition of the reported financial statements must be more accurate. 
Researchers Siregar and Utama (2005) found that firm size has a significant negative effect on earnings management, meaning that the larger company size, the smaller the amount of profit management.

On the other hand, Desmiyawati et al. (2013) found that firm size has a significant positive effect on earnings management.

Based on the explanation above, the hypothesis can be formulated as follows:

\section{$\mathrm{H}_{2}$ : Firm size has a significant effect on earnings management.}

\section{Managerial Ownership of Earnings Management}

Increasing managerial ownership can be used as a way to reduce agency conflicts. Managerial ownership companies align the position of managers with shareholders so they act according to the wishes of the shareholders. With the increase in the percentage of ownership, managers are motivated to improve performance and are responsible for increasing shareholder wealth. In this condition, agency conflicts are resolved by increasing managerial ownership. The ownership of a manager will determine the decision-making policies regarding the accounting methods applied to the companies they manage. A certain percentage of share ownership by management tends to reduce earnings management actions.

Widiatmaja's research (2010) states that: Managerial ownership has a significant positive effect on earnings management. A manager who also owns shares has a personal interest, namely the return obtained from his share ownership in the company. Thus, managers have the opportunity to better manipulate in the form of increasing profits or reducing profits. Meanwhile, Wiryadi and Sebrina (2013) state that managerial ownership has a significant negative effect on earnings management.

Based on the explanation above, it can be formulated as follows:

\section{$H_{3}$ : Managerial ownership has a significant effect on earnings management.}

\section{RESEARCH METHODOLOGY}

This type of research uses a quantitative research method approach. The definition of quantitative research methods according to Sugiyono (2018) can be interpreted as a research method based on the philosophy of positivity, used to research on certain populations or samples, data collection used quantitative / statistical data analysis research instruments, with the aim of testing predetermined hypotheses.

The independent variables used in this study are information asymmetry (X1), firm size $(\mathrm{X} 2)$, managerial ownership (X3) and the dependent variable is earnings management $(\mathrm{Y})$.

The dependent variable in this study is earnings management. Earnings management can be defined as a form of earnings reporting manipulation carried out by management to achieve certain goals, earnings management is said to be a process carried out deliberately by company management within the boundaries of generally accepted accounting principles to produce a desired level of profit (Desmiyawati, 2009). Earnings management is measured by proxy for discretionary accruals (DA) and calculated using the Modified Jones Model, because it can detect earnings management 
better than other models. To measure discretionary accruals, refers to the study of Dechow et al. (1995). The calculation of the amount of discretionary accruals is carried out in three stages, namely:

\section{Calculating Total Accruals}

Total accruals in this study use cash flow data from operating activation which is directly obtained from the cash flow statement. By using the cash flow statement approach, the total accruals are calculated as follows:

$\mathrm{TACC}_{\text {it }}=\mathrm{NI}_{\text {it }}-\mathrm{OCF}_{\text {it }}$

Explanation:

$\mathrm{NI}$ it $\quad$ : Net income of company $\mathrm{i}$ in year $\mathrm{t}$

$\mathrm{OCF}$ it : cash flow from operation company i year $\mathrm{t}$

TACC $_{\text {it }}$ : The total accruals of company $i$ in year $t$

\section{Calculating Non Discretionary Accruals}

To assess earnings management carried out within the company, the total value of accruals is divided into discretionary accruals and non-discretionary accruals. In calculating discretionary accruals, a modified Jones model is used because this model is considered the best among other models that are both used to detect earnings management (Dechow, Sloan, Sweeney, 1995). The calculation model is as follows:

$$
\mathrm{TACC}_{\mathrm{it}} / \mathrm{A}_{\mathrm{it}-1}=\beta_{1}\left(1 / \mathrm{A}_{\mathrm{it}-1}\right)+\beta_{2}\left(\left(\Delta \mathrm{REV}_{\mathrm{it}} / \mathrm{A}_{\mathrm{it}-1}\right)+\beta_{3}\left(\mathrm{PPE}_{\mathrm{it}} / \mathrm{A}_{\mathrm{it}-1}\right)+\varepsilon_{\mathrm{it}}\right.
$$

The total accrual equation above is estimated using the oridinary least square (OLS) method. Estimates of a1, a2, a3 are obtained from the OLS regression and are used to calculate non-discretionary accruals as follows:

$$
\operatorname{NDACC}_{i t}=\beta_{1}\left(1 / A_{i t-1}\right)+\beta_{2}\left(\left(\Delta R V_{i t}-\Delta R C_{i t}\right) / A_{i t-1}\right)+\beta_{3}\left(P_{P E} i t / A_{i t-1}\right)
$$

\section{Explanation:}
$\mathrm{A}_{\mathrm{it}-1} \quad$ : Total assets of company $\mathrm{i}$ in year $\mathrm{t}-1$
$\triangle R E V_{i t} \quad:$ The revenue of company $i$ in year $t$ is reduced Income in year $\mathrm{t}-1$
$\mathrm{PPE}_{\mathrm{it}} \quad$ : Fixed assets of company $\mathrm{i}$ in year $\mathrm{t}$
$\triangle \mathrm{REC}_{\mathrm{it}} \quad$ : Receivables from company $\mathrm{i}$ in year $\mathrm{t}$ less receivables in year $\mathrm{t}-1$
$\mathrm{NDACC}_{\mathrm{it}}$ : non discretionary accruals company $\mathrm{i}$ in year $\mathrm{t}$

\section{Calculating Discretionary Accruals}

In the last stage, discretionary accruals are estimated as follows:

$\mathrm{DACC}_{\mathrm{it}}=\left(\mathrm{TACC}_{\mathrm{it}} / \mathrm{A}_{\mathrm{it}-1}\right)-\mathrm{NDACC}_{\mathrm{it}}$ 
The independent variables in this study consist of information asymmetry, firm size and managerial ownership. Measurements for each of the independent variables used in the study can be explained as follows:

\section{Information Asymmetry}

Information asymmetry is a condition in which managers know more about the company's internal information and prospects in the future than shareholders of stakeholder funds (Wiryadi and Sebrina, 2013). This study measures the information asymmetry using the relative bid-ask spread by observing events or window periods (event windows) for 15 days around the announcement of the stock split, 7 days before the announcement, 1 day on the announcement date and 7 days after the announcement date. The calculation model is as follows:

$$
\operatorname{BIDASK}_{i, t}=\left(\operatorname{ask}_{i, t}-b_{i d}, t\right) /\left\{\left(\operatorname{ask}_{i, t}+b_{i d}, t\right) / 2\right\} \times 100
$$

The models for settling the spread are:

$$
\text { SPREAD }_{\mathrm{i}, \mathrm{t}}=\beta_{0}+\beta_{1} \text { PRICE }_{\mathrm{i}, \mathrm{t}}+\beta_{2} \text { VAR }_{\mathrm{i}, \mathrm{t}}+\beta_{3} \text { TRANS }_{\mathrm{i}, \mathrm{t}}+\beta_{4} \text { DEPTH }_{\mathrm{i}, \mathrm{t}}+\text { ADJSPREAD }_{\mathrm{i}, \mathrm{t}}
$$

Source: Muliati (2011)

Explanation:

ask $_{\mathrm{i}, \mathrm{t}} \quad$ : The highest ask price for company i shares that occurred in period $\mathrm{t}$

bid $_{i, t} \quad$ : The lowest bid price for company I shares that occurred in period $\mathrm{t}$

PRICE $E_{i, t}$ : The closing price of company i shares on day $t$

TRANS $_{i, t}$ : The number of transactions of a share of company $i$ on day

$\mathrm{t}$

VAR $_{i, t} \quad$ : Daily return variance during the study period on company $i$ and day $t^{\prime} s$ shares. Daily return is the percentage change in share price on day $t$ with the stock price on the previous day $(t-1) 2$

$\mathrm{DEPTH}_{\mathrm{i}, \mathrm{t}} \quad$ : Average number of shares of company i in all quotes (amount available on ask plus amount available at time of bid divided by two) during each day $t$

ADJSPREAD $i, t$ : The residual error is used as the adjusted SPREAD measure for firm i on day $\mathrm{t}$

\section{Company Size}

The size of the company shows the size of the assets owned by the company. In this study, the company size variable is measured by proxy using the logarithm of the company's total assets, or it can be written as follows:

$$
\text { Size/ company size }=\boldsymbol{L}_{\boldsymbol{o g}}(\text { total } \text { asset })
$$

Sumber : Dsmiyawati, dkk (2009) 


\section{Managerial ownership}

Managerial ownership is share ownership by management who actively participates in making decisions (directors and commissioners). To measure the managerial ownership variable is the percentage of the number of shares owned by management of all the company's share capital in circulation, or it can be written as follows:

$\mathrm{KM}=\%$ management shares of the total company shares

The Population used in this study is manufacturing companies listed on the Indonesia Stock Exchange for 2 years (2011-2012). The sampling technique in this study used non-probability sampling, namely purposive sampling.

The method of data analysis in this research consists of; Descriptive statistical analysis, classical assumption test (normality test, multicollinearity, heteroscedasticity test, and autocorrelation test).

After obtaining the data needed in this study, the researcher will calculate and process the data in order to achieve the hypothesis that has been proposed. The models formulated in this study are as follows:

$$
\mathrm{ML}=\beta_{0}+\beta_{1} \mathrm{AI}+\beta_{2} \mathrm{SIZE}+\beta_{3} \mathrm{KM}+\varepsilon
$$

Explanation:

ML = Profit management

AI $=$ Information asymmetry

Size = Company size

$\mathrm{KM}=$ Managerial ownership

$\varepsilon \quad=$ Error

The F statistical test basically shows whether all the independent variables used in the study have a simultaneous influence on the dependent variable. This test is performed using a significance level of $5 \%$. If the significance value $f<0.05$, it means that there is a significant influence between all independent variables on the dependent variable. If the value of $\mathrm{f}>0.05$ means that there is no influence between the independent variable on the dependent variable (Ghozali, 2016).

Partial testing shows how far the influence of one independent variable is in explaining the variation of the dependent variable (Ghozali, 2016). Hypothesis testing for each variable includes: information asymmetry, firm size and managerial ownership of earnings management. The significance level of the $t$ test in this study is a 0.05 .

\section{RESEARCH RESULTS AND DISCUSSION}

Based on the results of data testing that have been carried out, the following will explain the results of the research and discussion as follows: 


\section{Descriptive Statistical Analysis}

Descriptive statistical test aims to provide an overview or description of data seen from the number of samples, minimum value, maximum value, average value (mean), and standard deviation of each variable. Based on the processing results, the following results were obtained:

Figure 1

Descriptive Statistics

\begin{tabular}{lccccc}
\hline \multicolumn{1}{c}{ Variabel } & N & Minimum & Maximum & Mean & $\begin{array}{c}\text { Std. } \\
\text { Devation }\end{array}$ \\
\hline Profit management & 93 & 0,11 & 6,63 & 1,7316 & 0,91021 \\
Information & 93 & $-0,96$ & 0,82 & 0,1815 & 0,25919 \\
Asymmetry & 93 & 0,01 & 5,01 & 0,8632 & 0,91867 \\
Company Size & 93 & 0,22 & 0,32 & 0,2664 & 0,02488 \\
Managerial ownership & 93 & & & & \\
\hline Valid N (listwise) & & & & & \\
\hline
\end{tabular}

\section{Source: Processed data}

Based on table 1 above, it can show that the value of earnings management is 0.11 to 6.63 with an average value of 1.7316. When viewed from the range between the minimum and maximum values which are quite far away, it indicates that the sample companies in this study tend not to do earnings management.

The information asymmetry variable has the lowest value of -0.96 indicating that investors have sufficient information, and the highest value is 0.82 , this value indicates that management provides more information than the information held by investors. This indicates that investors have sufficient information about the condition of the company, so that they can pressure management in carrying out earnings management.

The lowest value of company size is 0.01 and the highest value is 5.01 . It can be concluded that larger companies have a greater incentive to perform earnings management.

Managerial ownership is 0.22 and the highest value is 0.32 . This value indicates that management has relatively low shares in the sample companies studied, namely $22 \%$ to $32 \%$. Due to the low ownership of management shares, the supervision carried out is not maximal, which will lead to incentives for company management to conduct earnings management.

The classic assumption test is used to test whether the regression model used in this study is worth testing or not. The classical assumption test is used to ensure that multicollinearity, autocorrelation, and heteroscedasticity are not present in the model used and the resulting data is normally distributed. From the classical assumption test above, it can be concluded that the data that has been tested is normally distributed so that it meets the requirements for model testing.

Pengujian model menggunakan Uji Adjusted $R$ Squre Uji T dan Uji F. Hasil pengujian model terhadap variabel-variabel penelitian disajikan pada Figure 2 berikut ini: 
Figure 2

Multiple Linear Regression Model Test Results

\begin{tabular}{lcccl}
\hline \multirow{2}{*}{ Variabel } & Coefficient & $\begin{array}{c}\text { Std. } \\
\text { Error }\end{array}$ & T & Pvalue \\
\hline Constant & 1,892 & 0,643 & 2,943 & 0,099 \\
AI & 2,770 & 0,232 & 11,922 & $0,000 * *$ \\
SIZE & 0,030 & 0,067 & $-0,445$ & $0,658 * * *$ \\
KM & $-2,586$ & 2,426 & $-1,066$ & $0,289 * * *$ \\
\hline R Square & 0,624 & \\
Adjusted R Square & 0,612 & \\
F & 4,286 & \\
Sig & 0,000 & \\
***,$* *$ * Statistically significant at the level 0,01, 0,05, 0,1 \\
Source: Processed data
\end{tabular}

Based on the regression results, the Adjusted (R2) value was 0.612. It can be concluded that the ability of the variable information asymmetry, firm size and managerial ownership in explaining the variance of earnings management variables is quite capable.

Based on the results of the analysis in Table 2, it is known that the variables of information asymmetry, company size and managerial ownership together have a significant effect on earnings management. This can be proven from the value of the significance level of 0.000 .

Based on the test results of the above hypothesis, the regression coefficient $\mathrm{H} 1$ is 11.922 with a significance value of 0.004 or less than 0.05 . It can be concluded that information asymmetry has a significant effect on earnings management. Thus the hypothesis proposed in this study is proven and accepted.

Based on the test results of the above hypothesis, the $\mathrm{H} 2$ regression coefficient value is 0.444 with a significance value of 0.658 or greater than 0.05 . It can be concluded that company size has no effect on earnings management. Thus the hypothesis proposed in this study is not proven and rejected.

Based on the test results of the above hypothesis, the regression coefficient H3 is - 1.066 with a significance value of 0.289 or greater than 0.05 . It can be concluded that managerial ownership has no effect on earnings management. Thus the hypothesis proposed in this study is not proven and rejected.

\section{Information asymmetry on earnings management}

Information asymmetry has a significant effect on earnings management. This means that managers as company managers know more about the company's internal information and prospects in the future than the owners (shareholders). Publicizing information to the public and potential investors will reduce earnings management practices.

In this study, managers are open and provide information in accordance with company conditions. So it can be concluded that investors have sufficient information about the condition of the company. The results of this study are inconsistent with research conducted by Desmiyawati (2009) which states that asymmetry has a significant positive effect on earnings management. The smaller the information that occurs, the smaller the occurrence of earnings management. 


\section{Firm size on earnings management}

Firm size has no effect on earnings management. However, with the result of the regression coefficient value of -0.444 it can be concluded that large-scale companies and strategic industries tend to carry out earnings management by reducing profits in order to reduce the level of visibility, especially during periods of high prosperity.

This effort is carried out in the hope of obtaining facilities and facilities from the government. Political costs arise because high corporate profitability can attract media and consumer attention. In addition, managers will try to pay the lowest possible tax by reducing their profits.

By reducing reported profits, companies can reduce the tax burden that must be paid to the government. The results of this study are inconsistent with the results of research conducted by Kusumawardhani (2012) which concluded that company size has a significant negative effect on earnings management. This means that the larger the size of the company, the smaller the earnings management is carried out by the company, where small companies are more likely to do earnings management than large companies.

\section{Managerial ownership of earnings management}

Managerial ownership has no effect on management. However, the regression coefficient value is -1.066 . It can be concluded that the possibility of disclosing earnings management is very high. This may occur because the involvement of the controlling shareholder's family in management does not provide positive relationship support. In fact, this creates a negative relationship with earnings management. With family control, agency problems will arise, because the family as the shareholder has control to increase their personal profits.

These results are inconsistent with the research conducted by Wiryadi and Sebrina (2013) that managerial ownership has a significant negative effect on earnings management, which states that share ownership by managers in the company can reduce the occurrence of earnings management practices because of their obligations.

\section{CONCLUSION}

Based on the results of the analysis and discussion that has been described, the conclusions of this study are as follows:

1. The results show that Information Asymmetry (X1) has a significant negative effect on Earning Management (Y). This is indicated by the p-value of 0.004 in other words, the hypothesis proposed in this study is proven and accepted.

2. The results show that firm size (X2) has no effect on earnings management $(Y)$. This is indicated by the p-value of 0.658 . In other words, the hypothesis proposed in this study is not proven and is rejected.

3. The results showed that Managerial Ownership (X3) had no effect on Earning Management (Y). This is indicated by the p-value of 0.289 in other words, the hypothesis proposed in this study is not proven and is rejected. 


\section{RESEARCH LIMITATIONS}

The research that has been carried out has research limitations which can later be used as a reference in conducting further research, including the following:

1. This study only uses a sample of companies in various industrial sectors, basic industries and chemicals.

2. The observation period in this study is very short, namely only in 2017-2019.

3. This study only uses three independent variables, namely information asymmetry, company size and managerial ownership. The result is that only the information asymmetry variable has an effect while firm size and managerial ownership have no effect on earnings management.

\section{RECOMMENDATION}

Researchers realize that this research is far from perfect. For this reason, the researcher provides recommendations for further research as follows:

1. The sample used for further research should add and expand the types of companies in other sectors in order to obtain more accurate analysis results.

2. The period used should be longer in order to obtain better results.

3. Further research should add other corporate governance variables (the Board of Commissioners and the Audit Committee), which can improve the quality of financial reports, because management will tend not to manipulate financial reports, because of the obligation to comply with various accounting rules, principles and the transparent presentation of information.

\section{DAFTAR KEPUSTAKAAN}

Abdul, Halim, 2005. Analisa Investasi. Edisi Kedua. Jakarta: Salemba Empat.

Agusti, R \& Pramesti, T. 2009. Pengaruh Asimetri Informasi, Ukuran Perusahaan, Kepemilikan Manajerial Terhadap Manajemen Laba. Jurnal Ekonomi. Volume 17, No 01.

Aida Ainul Mardiyah dan Gudono, 2001. Pengaruh Ketidakpastian Lingkungan Dan Desentralisasi Terhadap Karakteristik Informasi Sistem Akuntansi Manajemen. Jurnal Riset Akuntansi Indonesia, Vol. 4

Anthony, Robert N dan Vijay Govindarajan. 2005. Management Control System Buku 2. Jakarta: Salemba Empat

Arif, Ujiyanto Moh dan Bambang Agus Pramuka. 2007. Mekanisme Corporate Governance, Manajemen Laba, dan Kinerja Keuangan. Simposium Nasional Akuntansi X. IAI.

Ardi Murdoko Sudarmadi dan Lana Sularto. 2007, Ukuran Perusahaan, Profitabilitas, Leverage dan Tipe Kepemilikan Terhadap Luar Voluntari Disclosure Laporan Keuangan Tahunan, Prociding Pesat, Vol 2.

Arri Wiryad dan Nurzi Sebrina, Pengaruh Asimetri Infomasi, Kualitas Audit dan Struktur Kepemelikan Terhadap Manajemen Lana, Wahana Reset Akuntansi, Vol 1, No,2, 2014.

Dechow et al. (1995)., Couses and Consequences of Earning Manipulation; Analysis of Firm Subject to Enforcement Actions by The SEC, Contermporary Accounting Research. 
Dechow, P.M., R.G Sloan, and A.P. Sweeney. 1996. Causes and Consequences of Earnings Manipulation: Analysis of Firms Subject to Enforcement Actions by The SEC, Contermporary Accounting Research.

Desmiyawati, Nasrizal \& Yessi Fitriana (2009), Pengaruh Asimetri Informasi dan Ukuran Perusahaan Terhadap PraktikManajemen Laba pada Perusahaan Manufaktur yang Terdaftar di Bursa EfekIndonesia, Pekbis Jurnal, Vol.1, No.3, 180-189.

Ghozali, Imam. 2016. Aplikasi Analisis Multivariete Dengan Program IBM SPSS 23 (Edisi 8). Cetakan ke VIII. Semarang : Badan Penerbit Universitas Diponegoro.

Halid, F. 2015. Pengaruh Non Performing Financing Terhadap Pembiayaan Murabahah, Mudharabah, dan Musyarakah pada Bank Umum Syariah di Indonesia. Jurnal Akuntansi \& Bisnis, Vol I, No. 1.

Jensen \& Meckling, 1976, The Theory of The Firm ; Managerial Behaviour Agency Cost, and Ownership Structure, Journal of Financial and Economics, 3:305-360

Listyani, Theresia Tyas., 2003, Kepemilikan Manajerial, Kebijakan Hutang, dan Pengaruhnya Terhadap Kepemilikan Saham Institusional (Studi pada Perusahaan Manufaktur di Bursa Efek Jakarta), Jurnal Maksi, Vol 3, Agustus,98114.

Nadia Dhaneswari dan Retnaningtyas Widuri, 2013, Pengaruh Asimetri, Ukuran Perusahaan dan Beban Pajak Tangguhan Terhadap Praktik Manajemen Laba, Tax \& Accountig Review, Vol, 3, No,2.

Nasution, Marihot dan Doddy Setiawan. 2007. Pengaruh Corporate Governance terhadap Manajemen Laba di Industri Perbankan Indonesia. Simposium Nasional Akuntansi X.IAI.

Nuryaman, 2009, Pengaruh Konsentrasi Kepemilikan, Ukuran Perusahaan dan Mekanisme Corporate Governance Terhadap Pengungkapan Sukarela, Jumal Akuntansi dan Keuangan Indonesia, Volume 6 - Nomor 1.

Rahmawati, dkk. 2006. Pengaruh Asimetri Informasi terhadap Praktik Manajemen Laba pada Perusahaan Perbankan Publik yang terdaftar di Bursa Efek Jakarta, Simposium Nasional Akuntansi IX.

Scott,William R.2000.Financial Accounting Theory.USA:Prentice-Hall.

Sugiyono. 2018. Metode Penelitian Kuantitatif, Kualitatif, dan R\&D. Bandung: Alfabeta Ujiyantho, Moh. Arief dan Bambang Agus P. 2007. "Mekanisme Corporate Governance, Manajemen Laba dan Kinerja Keuangan” ,Simposium Nasional Akuntansi X,IAI

Watts, R. L., and Zimmerman, J.L. 1990. "Positive Accounting Theory: A Ten Year Perspective." American Accounting Association, 131-156.

Widiatmaja, Bayu Fatma, 2010. Pengaruh Mekanisme Corporate Governance terhadap Manajemen Laba dan Konsekuensi Manajemen Laba terhadap Kinerja Keuangan. Semarang: Universitas Diponegoro. 